\title{
H2-DILUTION VS. BUFFER LAYERS FOR INCREASED V
}

R. PLATZ, D. FISCHER, C. HOF, S. DUBAIL, J. MEIER, U. KROLL AND A. SHAH

Institut de Microtechnique, Université de Neuchâtel

Rue A.-L. Breguet 2, CH-2000 Neuchâtel, Switzerland

\begin{abstract}
Hydrogen dilution and buffer layers, as two ways to obtain higher $\mathrm{V}_{\mathrm{Oc}}$ values in a-Si:H p-i-n solar cells, are directly compared in the present study. Special emphasis is laid on stability against light soaking. $\mathrm{H}_{2}$-dilution in combination with lower substrate temperature yields higher $\mathrm{V}_{\mathrm{OC}}$ values and better stability as compared to buffer layers. However, light absorption is decreased due to the increased gap in $\mathrm{H}_{2}$-diluted cells. The stability of buffer layer cells can remarkably be ameliorated by boron doping and $\mathrm{H}_{2}$-dilution of the a-SiC:H buffer layer. However, stabilized efficiency is higher for optimized diluted cells than for cells with a buffer layer. An a-Si/a-Si stacked cell with a graded dilution for both cells yielded $10 \%$ initial efficiency with $17 \%$ relative degradation. Diluted a-Si:H cells at lower temperature become specially interesting in combination with a microcrystalline bottom cell. For such a "micromorph" tandem cell we obtained $11.4 \%$ initial efficiency.
\end{abstract}

\section{INTRODUCTION}

There are different approaches to increase the $\mathrm{V}_{\mathrm{OC}}$ of a-Si:H based p-i-n solar cells. One is to use wide-bandgap a-SiC:H buffer layers at the p-i-interface, another to use lower deposition temperatures for the i-layer thereby increasing the bandgap energy. Both methods are found to be harmful to the stability of the cells.

It has been shown that the stability of buffer cells can be increased by boron-doping of the buffer layer and hydrogen dilution of the buffer a-SiC:H material [1],[2]. For lower deposition temperatures, $\mathrm{H}_{2}$-dilution is found to increase the material quality of the i-layer and also the stability of the cells [3],[4].

The present study compares both methods with respect to their potential to increase the $\mathrm{V}_{\mathrm{OC}}$ and their influence on the stability of solar cells. The study was realized with materials and cells deposited by VHF-GD at $70 \mathrm{MHz}$.

\section{H2-DILUTION}

\section{MATERIAL}

If one wants to increase the bandgap of a-Si:H intrinsic material in order to obtain a higher open-circuit voltage for a $\mathrm{p}-\mathrm{i}-\mathrm{n}$ solar cell, hydrogen dilution can play a double role. On the one hand, the quality of material deposited below "standard" temperature (a technique that increases the bandgap) is remarkably enhanced by $\mathrm{H}_{2}$-dilution. On the other hand, hydrogen dilution increases the bandgap of the material at a given temperature already by itself.

We investigated the influence of hydrogen dilution on material properties for 3 temperatures and different dilution ratios $\left(\left[\mathrm{H}_{2}\right] /\left[\mathrm{SiH}_{4}\right]\right)$. The substrate temperatures were $220^{\circ}, 180^{\circ}$ and $120^{\circ} \mathrm{C}$. The extent of hydrogen dilution is limited by the transition between amorphous and microcrystalline growth. This transition occurs for our VHF deposition technique $(70 \mathrm{MHz})$ at dilution ratios of about 12 to 15 (with conventional RF

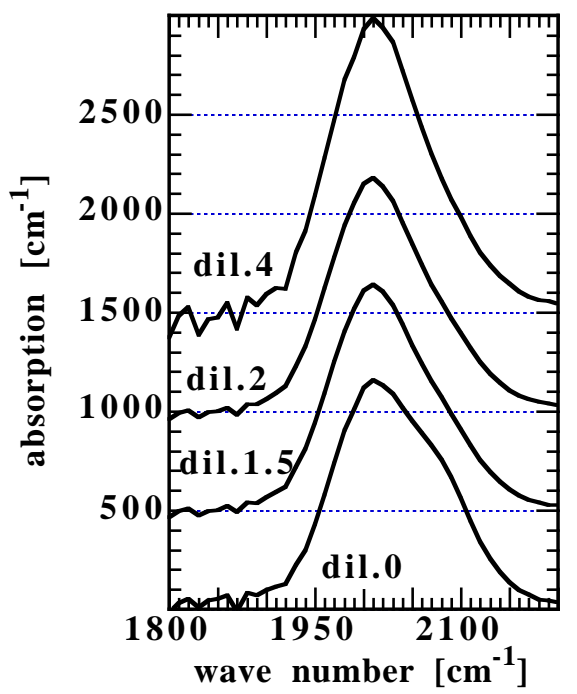

Fig.1.: Infrared absorption spectra for layers deposited at $120^{\circ} \mathrm{C}$ and different hydrogen dilution ratios. The spectra are shifted by $500 \mathrm{~cm}^{-1}$ with respect to each other. 
$(13.56 \mathrm{MHz})$ deposition the onset of microcrystalline growth is typically at ratios of 30 to 50 [5]).

We observed a remarkably better microstructure, as determined from the $2000 \mathrm{~cm}^{-1}$ and $2080 \mathrm{~cm}^{-1}$ IR absorption peaks, for samples deposited at low temperature with hydrogen dilution as compared to undiluted samples (at the same deposition temperature). Fig.1. shows those peaks for the $120^{\circ} \mathrm{C}$ samples and for different dilution ratios. The $2080 \mathrm{~cm}^{-1}$ peak clearly decreases with increasing $\mathrm{H}_{2}$-dilution. For samples deposited at "standard" temperature, i.e. at $220^{\circ} \mathrm{C}$, this peak is, already for undiluted samples, much smaller than the $2000 \mathrm{~cm}^{-1}$ peak.

The fact that $\mathrm{H}_{2}$-dilution increases the quality of a-Si:H deposited at low temperatures is also confirmed by determination of the material quality parameter $\mu_{0} \tau_{0}$ [6]: Fig.2. shows $\mu_{0} \tau_{0}$ for the samples deposited at $120^{\circ} \mathrm{C}$, indicating better electronic transport properties with increasing dilution.

\section{$\underline{\text { CELLS }}$}

In order to study the influence of hydrogen dilution of the i-layer on cell performance in the initial as well as in the degraded state, we deposited 2 series of cells $\left(220^{\circ} \mathrm{C}\right.$ and $\left.180^{\circ} \mathrm{C}\right)$ containing the i-layers mentioned above. The i-layer thickness was chosen to be $450 \mathrm{~nm}$, i.e. much thicker than for high-performance solar cells; the i-layer quality thereby directly determines the cell performance, and possible harmful effects cannot be easily hidden behind field-enhanced collection, as in cells with thinner i-layers. These series of cells were systematically degraded for $1000 \mathrm{~h}$ at $50^{\circ} \mathrm{C}$ under white

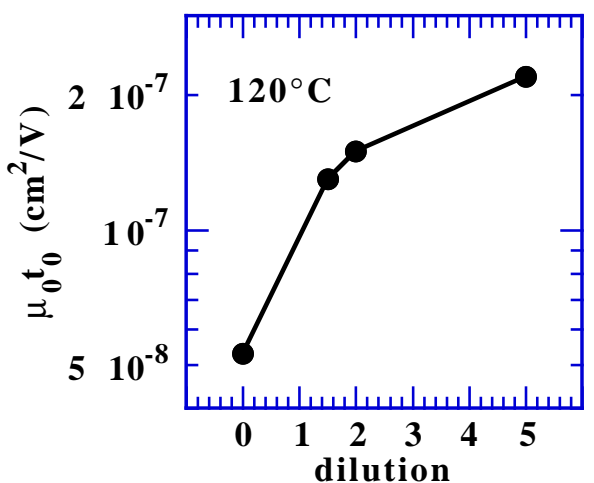

Fig.2.: $\mu_{0} \tau_{0}$ for samples deposited at $120^{\circ} \mathrm{C}$ and different dilution ratios. The samples are the same as in Fig.1.

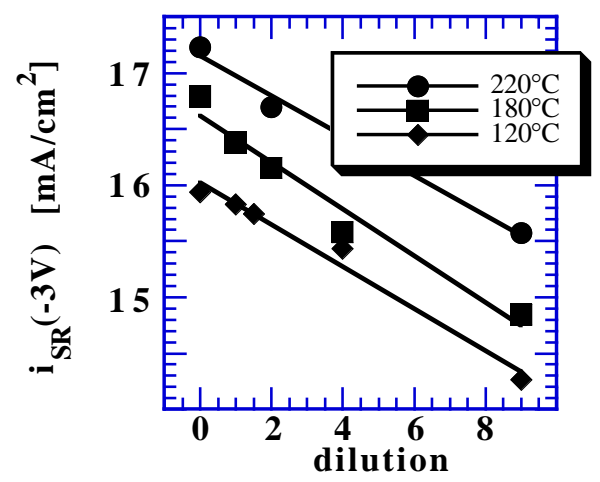

Fig.3.: Current from integrated SR(-3V) for $450 \mathrm{~nm}$ thick i-layers as a measure of the optical absorption as a function of substrate temperature and hydrogen dilution. light (1 sun intensity) and open circuit conditions.

For constant deposition temperature we observe an increase of the optical gap with hydrogen dilution as is reflected in spectral response (SR) measurements. The integrated current from spectral response measurements at $-3 \mathrm{~V}$ bias voltage (no collection losses) is a measure for the absorbed photons and therefore the optical gap. This current decreases strongly with increasing hydrogen dilution and, to a smaller extent, with decreasing deposition temperature (Fig.3.), indicating in both cases an increase in the optical gap.

The increase in the optical gap is reflected in the $V_{O c}$ values for these cells (Fig.4a.). For undiluted cells, the value of $\mathrm{V}_{\mathrm{OC}}$ in the initial state is about $40 \mathrm{mV}$ higher for cells deposited at $180^{\circ} \mathrm{C}$ than for cells deposited at $220^{\circ} \mathrm{C}$ (standard temperature), whereas the difference in the gap is only about $20 \mathrm{meV}$. Similar results have already been reported elsewhere [4]. The increase in $\mathrm{V}_{\mathrm{OC}}$ obviously does not only depend on the optical gap $\mathrm{E}_{\mathrm{g}}$. This indicates that other mechanisms play a role: e.g. less recombination in the bulk due to better material quality or/and different interfaces for diluted i-layers.

For the $180^{\circ} \mathrm{C}$ samples, $V_{\text {OC }}$ decreases slightly under degradation (except the sample at dilution 9, where $\mathrm{V}_{\mathrm{OC}}$ increases) whereas the $\mathrm{V}_{\mathrm{OC}}$ values for the $220^{\circ} \mathrm{C}$ samples even slightly increase. (See also similar observations in [1],[7]). Hydrogen dilution improves the fill factor after degradation for the cells deposited at $180^{\circ} \mathrm{C}$. For the $220^{\circ} \mathrm{C}$ cells, the degraded fill factor is only slightly improved by $\mathrm{H}_{2}$-dilution. However, for both temperatures, current degradation is strongly reduced by $\mathrm{H}_{2}$-dilution (Fig.4b.).

The observed gain in $\mathrm{V}_{\mathrm{OC}}$ and the stabilized fill factor have to compete with losses in current due to the higher optical gap. An increase of the $\mathrm{V}_{\mathrm{Oc}}$ from $0.83 \mathrm{~V}$ up to $0.90 \mathrm{~V}$ corresponds to $8.4 \%$ relative gain. The current (at $-3 \mathrm{~V})$ decreases from $17.2 \mathrm{~mA} / \mathrm{cm}^{2}\left(220^{\circ}\right.$, undil.) to 
$16.2 \mathrm{~mA} / \mathrm{cm}^{2}\left(180^{\circ}\right.$, dil.2) or even to $15.4 \mathrm{~mA} / \mathrm{cm}^{2}$ $\left(180^{\circ}\right.$, dil.9) which corresponds to $6.2 \%$ and $15.4 \%$ relative loss. For the $220^{\circ} \mathrm{C}$ samples, the higher $\mathrm{V}_{\mathrm{OC}}$ is compensated by the lower current, whereas for the $180^{\circ} \mathrm{C}$ samples the gain in $\mathrm{V}_{\mathrm{Oc}}$ and $\mathrm{FF}$ after degradation is larger than the loss in current. For dilution ratios of 2 and higher, both series have the same efficiency in the degraded state, one cell having a higher current and smaller $\mathrm{V}_{\mathrm{OC}}$, the other cell the inverse. This possibility of a choice between current and voltage is particularly interesting in the context of tandem and stacked cells.

It is quite clear that for thin cells, e.g. for the application as a top cell, the loss in the absorption can be compensated by a only slightly thicker i-layer, so in this case the diluted samples become even more interesting due to their high $\mathrm{V}_{\mathrm{OC}}$ and increased stability.

\section{CONTAMINATION PROBLEMS}

For high dilution ratios $(>2)$, we found that contamination problems play an increasing role. The main problem is oxygen contamination of the i-layer for highly diluted cells [8]. Due to the reduced growth rate and possibly due to traces of water in the feedstock gases, oxygen is incorporated into the i-layer. Oxygen acts as an n-type dopant [9]. In the solar cell, this leads to a reduced spectral response for red light, which in its turn leads to a low fill factor. Fig.5. shows the values of $\mathrm{V}_{\mathrm{Oc}}$ and of $\mathrm{FF}^{*}=\mathrm{FF} \cdot \mathrm{I}_{\mathrm{SC}} / \mathrm{I}(-3 \mathrm{~V})$ for highly diluted cells, deposited at different outgassing rates of the reactor walls. The fill factor decreases with increasing outgassing rate due to an increasing amount of n-type doping, whereas $\mathrm{V}_{\mathrm{OC}}$ is almost not affected. From this we conclude that water vapor coming from the walls is one major source of oxygen contamination The relative degradation of the collection is not affected by oxygen contamination.

Even for very low outgassing rates the $\mathrm{FF}^{*}$ values of the cells shown in Fig.5. do not exceed 60\% indicating that there is another problem persistent: it was found that the $\mathrm{H}_{2}$-diluted silane-plasma during the deposition of the i-layer etches the reactor walls. As cells were prepared in a single-chamber reactor, there is phosphor from previous depositions which is thereby etched and incorporated into the i-layer in spite of a dummy-layer deposited in between 2 cells. Deposition of this dummylayer at low pressure and with $\mathrm{H}_{2}$-dilution eliminated this problem.

Another source for n-type doping of the i-layer are impurities in the feedstock gas. The use of a gas purifier was shown to reduce these impurities [8]. By applying this technique to high dilution cells, we were able to further increase $\mathrm{FF}^{*}$ to over $64 \%$. This leads to the cells shown in Fig.4.

Remark: we also observe an etching of the p-layer during the deposition of a diluted i-layer; this results in a slight boron doping of the first part of the i-layer. This etching effect seems to

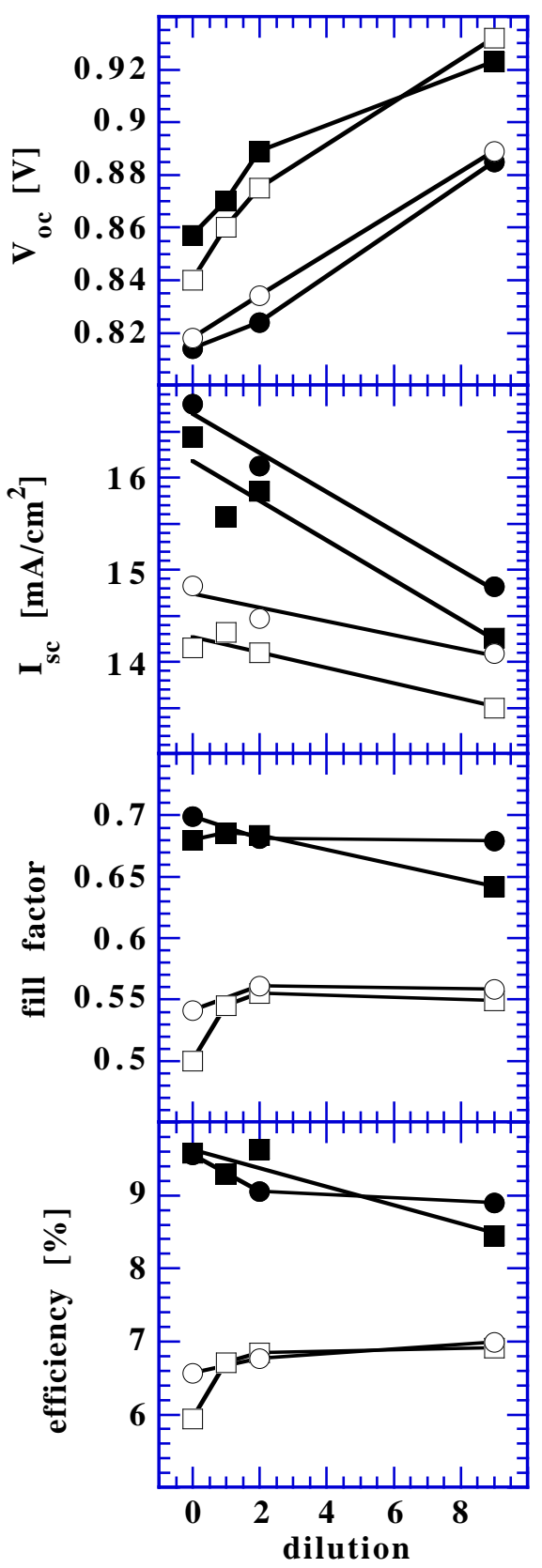

Fig.4a.: $V_{\text {Oc }}$ values for $220^{\circ}$ and $180^{\circ} \mathrm{C}$ and different dilution rates before and after degradation. i-layer thickness is $450 \mathrm{~nm}$. Circles: $220^{\circ} \mathrm{C}$, rectangles: $180^{\circ} \mathrm{C}$, filled symbols before degradation and open symbols after degradation (1000h).

Fig.4b.: $\mathrm{I}_{\mathrm{Sc}}$ values for the same samples.

Fig.4c.: Fill factor values for the same samples.

Fig.4d.: Efficiency values for the same samples. 
occur only for VHF deposition as it has to our knowledge so far not been reported for RF deposition at 13.56 MHz.

\section{BUFFER LAYERS}

It is well known that a buffer layer at the p-iinterface can remarkably increase the $\mathrm{V}_{\mathrm{OC}}$ of the cell. However, those cells suffer in general from poor stability due to the strong degradation of the buffer layer which destroys the electric field in the cell. It has been found [1], [2 (SiC-cells)] that boron doping of the buffer layer can reduce this effect by compensating negatively charged light-induced dangling bonds through positively charged boron atoms, thereby maintaining the electric field in the cell.

These findings encouraged us to further optimize buffer layers in order to find an answer to the question whether buffer layers can contribute to higher stabilized cell efficiencies through higher $\mathrm{V}_{\mathrm{OC}}$ values.

When optimizing those buffer layers, it is quite difficult to distinguish between degradation due to the buffer layer and degradation due to the bulk of the ilayer. We therefore used cells with an i-layer of $1000 \AA$ thickness and deposited with a $\mathrm{H}_{2}$ dilution ratio of 9 . Substrate temperature was $180^{\circ} \mathrm{C}$. The degradation of this i-layer itself is very small (Fig.6., triangles) and can therefore be considered to be negligible w.r.t. the degradation of the buffer layer.

Fig.6. shows a series of cells containing buffer layers with a varying doping concentration, deposited with $60 \% \mathrm{CH}_{4}, 40 \% \mathrm{SiH}_{4}$ and $\mathrm{H}_{2}$-dilution ratio of 10 .

Fig.6. shows that this buffer layer can increase the initial $\mathrm{V}_{\mathrm{OC}}$ to values of up to $1 \mathrm{~V}$. Fig.6. further confirmes that an adequate doping of the buffer layer can increase the fill factor in the initial state and reduce its degradation. (Results are quite similar to those reported in [2].) However, for all cells, independent of the doping level, there is no gain in $\mathrm{V}_{\mathrm{OC}}$ after degradation and the fill factor is always worse than for cells without a buffer. In order to increase the stability of the buffer layer itself we optimized the a-SiC:H material. Less $\mathrm{CH}_{4}$ in the gas phase and higher $\mathrm{H}_{2}-$ dilution ratios result in a better and more stable material [2]. With a new buffer layer $\left(40 \% \mathrm{CH}_{4}\right.$ in the gas phase, dilution ratio of the buffer layer 20 and appropriate doping (100ppm $\left.\mathrm{B}_{2} \mathrm{H}_{6}\right)$ ), we obtained the following result: $\mathrm{V}_{\mathrm{OC}}=0.955 \mathrm{~V}$ at $70 \% \mathrm{FF}$ which degrades after $1000 \mathrm{~h}$ to $0.933 \mathrm{~V}$ at $64.5 \% \mathrm{FF}$ (diamonds, Fig.6.). In this case there remains a gain in $\mathrm{V}_{\mathrm{Oc}}$ of $30 \mathrm{mV}$ after degradation.

It is shown that it is possible to reach $V_{\mathrm{OC}}$ values of $1 \mathrm{~V}$ with a buffer layer. The loss in $\mathrm{V}_{\mathrm{Oc}}$ and $\mathrm{FF}$ during degradation is clearly only due to the degradation of the buffer layer itself. If this degradation can be reduced, it should be possible to reduce $\mathrm{V}_{\mathrm{Oc}}$ degradation and maintain high values in the light-soaked state.

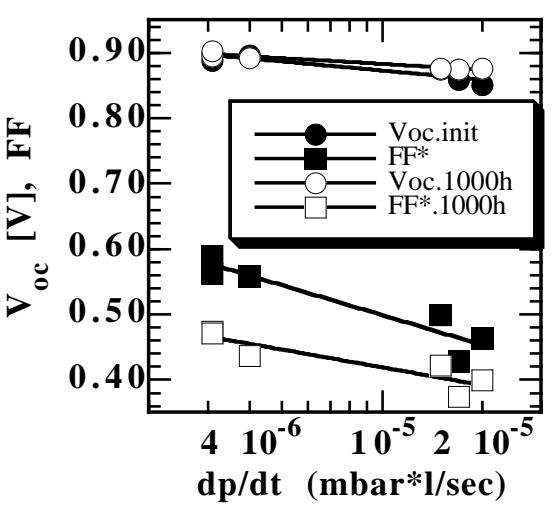

Fig.5.: $\mathrm{V}_{\mathrm{Oc}}$ and $\mathrm{FF}^{*}$ in the initial and degraded state for cells deposited at different outgassing rates of the reactor walls $[\mathrm{mbar} \cdot 1 / \mathrm{sec}] . \mathrm{FF}^{*}=\mathrm{FF} \cdot \mathrm{I}_{\mathrm{Sc}} / \mathrm{I}(-3 \mathrm{~V})$ is shown as for thick cells collection at $0 \mathrm{~V}$ already suffers from field distortion. Dilution of the i-layer was 9 , substrate temperature $180^{\circ} \mathrm{C}$ and ilayer thickness $450 \mathrm{~nm}$.

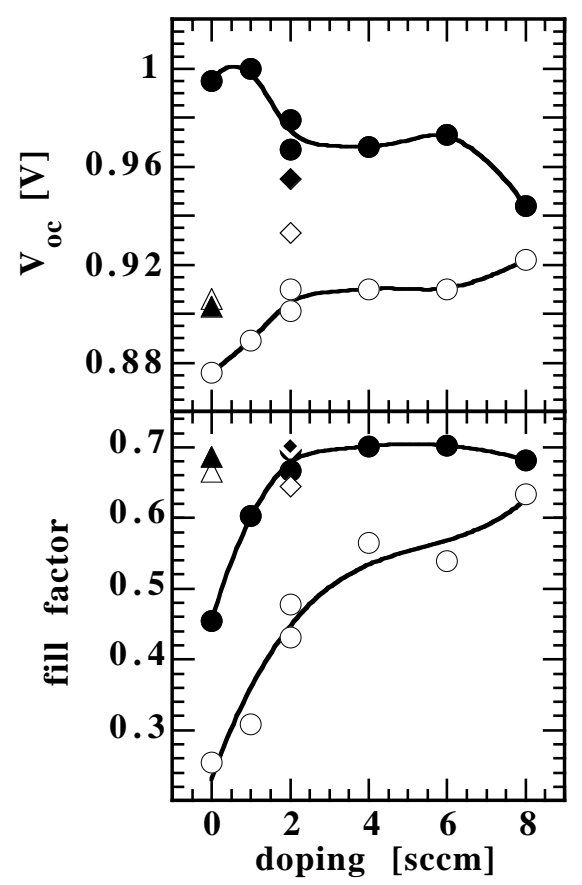

Fig.6a.: $V_{\text {oc }}$ for cells with a buffer layer in the initial (filled) and the degraded (open symbols) state for different doping fluxes $\left(\mathrm{B}_{2} \mathrm{H}_{6} 500 \mathrm{ppm}\right.$ in $\left.\mathrm{H}_{2}\right)$ for the buffer and comparison to a cell without buffer layer (triangles). i-layer thickness is $1000 \AA$. Diamonds indicate the so far best cells with a buffer layer.

Fig.6b.: FF for the same cells before and after degradation. 


\section{COMPARISON OF H2-DILUTION AND BUFFER LAYERS}

Fig.7. compares the so far best diluted cell in the degraded state (dil.2, $180^{\circ} \mathrm{C}$, see Fig.4.) to a cell with an undiluted i-layer but an optimized doped buffer layer at the p-i-interface. The buffer layer is the same as described above $\left(40 \% \mathrm{CH}_{4}\right.$, dil.20, doped). Both cells have an i-layer thickness of $450 \mathrm{~nm}$.

Although the buffer layer in Fig.7. is an optimized buffer layer, i.e. deposited with hydrogen dilution and boron doping, we observe a strong degradation under illumination. $\mathrm{V}_{\mathrm{OC}}$ degrades down to values only about $20 \mathrm{mV}$ above those without buffer layer and also the fill factor degradation is high. If we compare this cell to the cell deposited under $\mathrm{H}_{2}$ dilution at lower temperature, we find less $\mathrm{V}_{\mathrm{OC}}$ and $\mathrm{FF}$ degradation; this overcompensates the loss in current and results in a higher stabilized efficiency.

\section{STACKED CELLS}

For application in stacked cells we developed cells with a graded dilution ratio in the i-layer. A small part $(\approx 30 \mathrm{~nm})$ of the i-layer was deposited with a dilution of 9 in order to get the maximum possible voltage of around $900 \mathrm{mV}$ per cell, and the bigger part was deposited with a dilution of 2 in order to get sufficient current. In a $2000 \AA$ thick single cell we obtained by this structure $(1: 9 / 1: 2)$ a $\mathrm{V}_{\text {Oc }}$ of $927 \mathrm{mV}$ at $72.3 \% \mathrm{FF}$. In an a-Si/a-Si stacked cell, employing two times this structure, we obtained a $\mathrm{V}_{\mathrm{OC}}$ of $1.82 \mathrm{~V}$ at $73 \%$ fill factor and a current of $7.52 \mathrm{~mA} / \mathrm{cm}^{2}$ (efficiency of $10 \%$ ). Degradation of this cell is shown in Fig.8. Stabilization occurs after $\approx 300 \mathrm{~h}$ illumination at $8.3 \%$ efficiency which means $17 \%$ relative degradation. Inserting additionally a buffer layer as described above $\left(40 \% \mathrm{CH}_{4}\right.$, dil. 20) in both cells increases the $\mathrm{V}_{\mathrm{Oc}}$ to $1.9 \mathrm{~V}$. However, after degradation we observed no gain in efficiency when compared to the cell without buffer layers.

Recently our group published results on so-called micromorph tandem cells i.e. a-Si/microcrystalline stacked cells [10]. The best result at that time was a cell with a stabilized efficiency of $8.9 \%$. The top cell of this tandem was a $220^{\circ} \mathrm{C}$ undiluted cell with a doped buffer layer; the initial $\mathrm{V}_{\mathrm{Oc}}$ had been $1.25 \mathrm{~V}$ which degraded to $1.22 \mathrm{~V}$. Taking into account the results shown in this paper, we now deposited a "micromorph" tandem cell with a $180^{\circ} \mathrm{C}$ top cell, without buffer layer, but with a graded dilution 1:9/1:2. Thereby we could increase the $\mathrm{V}_{\mathrm{Oc}}$ to $1.34 \mathrm{~V}$ at $73.8 \% \mathrm{FF}$. $\mathrm{I}_{\mathrm{SC}}$ was $11.5 \mathrm{~mA} / \mathrm{cm}^{2}$ resulting in an initial efficiency of $11.4 \%$ [11]. In contrast to the former cell and as can be expected from the above result, there is nearly no $\mathrm{V}_{\mathrm{Oc}}$ degradation for this cell. After $145 \mathrm{~h}$ of light-soaking we measured $1.33 \mathrm{~V}$ at $66.6 \% \mathrm{FF}$ ( $9.9 \%$ efficiency).

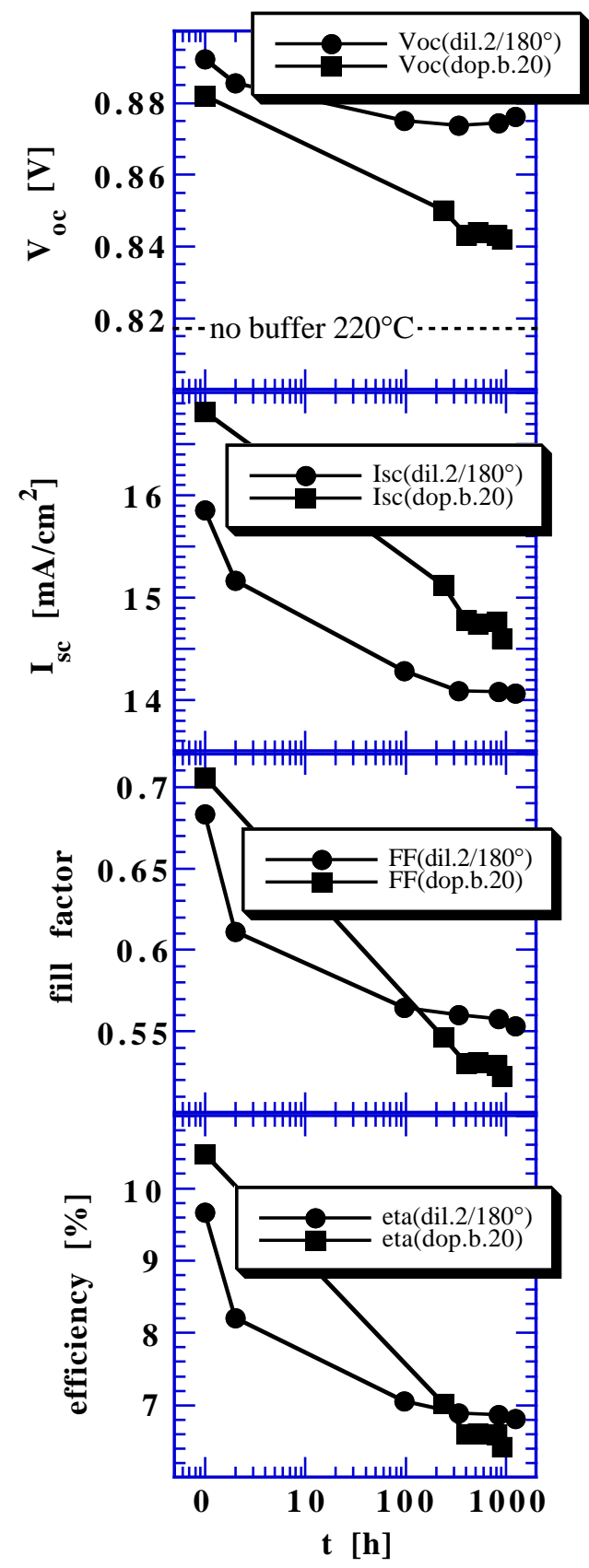

Fig.7a.: Comparison of Voc degradation for cells with doped a-SiC:H buffer (dilution 20) deposited at $220^{\circ} \mathrm{C}$ vs. diluted i-layer deposited at $180^{\circ} \mathrm{C}$ (thickness $450 \mathrm{~nm}$ ).

Fig.7b.: I $\mathrm{I}_{\mathrm{Sc}}$ degradation for the same cells.

Fig.7c.: FF degradation for the same cells.

Fig.7d.: Efficiency during degradation for the same cells. 


\section{CONCLUSIONS}

Hydrogen dilution as well as lower substrate temperature can remarkably enhance the $\mathrm{V}_{\mathrm{Oc}}$ values of $\mathrm{a}-\mathrm{Si}: \mathrm{H}$ p-i-n solar cells. In the latter case, $\mathrm{H}_{2}$-dilution avoids the material deterioration in the initial state (normally associated with low substrate temperatures), as well as enhanced degradation. At the same time, the maximum achievable current of the cells is reduced due to an increase in the optical gap. Further, $\mathrm{H}_{2}$-dilution reduces current degradation of thick cells, independently of the deposition temperature. As a result, after degradation, the efficiency of diluted cells is better than for standard undiluted cells.

For deposition with high $\mathrm{H}_{2}$-dilution ratios, contamination problems have to be looked at carefully in order to avoid detrimental effects on the cell performance.

Buffer layers can additionally contribute to even higher voltages. Highly diluted a-SiC:H material with slight boron doping yields buffer layers that enable a gain in $\mathrm{V}_{\mathrm{Oc}}$ which also remains in the degraded state. However, at present, cells with a buffer layer still degrade to lower efficiency values as compared to optimized diluted cells without a buffer layer.

Stacked cells with low degradation and high $\mathrm{V}_{\mathrm{OC}}$ demand a careful choice of the incorporated materials taking into account the achievable current for a given bandgap energy and cell thicknesses in order to minimize degradation. With a graded dilution of the i-layer we obtained for a a-Si/a-Si stacked cell an initial efficiency of $10 \%$ with only $17 \%$ relative degradation. It should be possible to increase the stability by stronger dilution of the top cell. In order to get enough current in both cells, the i-material for the bottom cell has to be reviewed.

$\mathrm{H}_{2}$-dilution and low substrate temperatures have also been applied to the top cell in a "micromorph" tandem cell resulting in an increase of the $\mathrm{V}_{\mathrm{Oc}}$ value. The results are reported in detail in a separate paper in this conference [11].

\section{ACKNOWLEDGMENTS}

Financial support by CERS (project 2745.1) and OFEN (project EF REN(93)032) is gratefully acknowledged.

\section{REFERENCES}

[1] B. Rech, C. Beneking, U. Zastrow and H. Wagner, Proc. 12th EC PVSEC, Amsterdam (1994) 1245.

[2] R. Platz, D. Fischer and A. Shah, MRS Symp. Proc. 377 (1995) 645.

[3] J. Yang, A. Banerjee, T. Glatfelter, K. Hoffman, X. Xu and S. Guha, Proc. 1st WCPEC, Hawaii (1994) 380.

[4] M. Bennett, K. Rajan and K. Kritikson, Proc. 23rd IEEE PVSC, Louisville (1993) 845.

[5] M. Kolter, C. Beneking, D. Pavlov, T. Eickhoff, P. Hapke, S. Frohnhoff, H. Münder and H. Wagner, Proc. 23rd IEEE PVSC, Louisville (1993) 1031.

[6] N. Beck, A. Shah, N. Wyrsch, Proc. 1st WCPEC, Hawaii (1994) 476.

[7] S. Wieder, B. Rech, C. Beneking, F. Siebke, W. Reetz and H. Wagner, Proc. 13th EC PVSEC, Nice (1995) 234.

[8] U. Kroll, J. Meier, H. Keppner and A. Shah, S.D. Littlewood and I.E. Kelly, P. Giannoulès, J. Vac. Sci. Technol. A 13(6) (1995) 2742.

[9] M. Isomura, T. Kinoshita, Y. Hishikawa and S. Tsuda, Appl. Phys. Lett. 65 (18) (1994) 2329.

[10] J. Meier, S. Dubail, D. Fischer, J.A. Anna Selvan, N. Pellaton Vaucher, R. Platz, C. Hof, R. Flückiger, U. Kroll, N. Wyrsch, P. Torres, H. Keppner, A. Shah, K.-D. Ufert, Proc. 13th EC PVSEC, Nice (1995) 1445.

[11] J. Meier, P. Torres, R. Platz, S. Dubail, U. Kroll, J.A. Anna Selvan, N. Pellaton Vaucher, C. Hof, D. Fischer, H. Keppner and A. Shah, K.-D. Ufert, P. Giannoulès, J. Köhler, this conference. 